\title{
Enhanced production, purification and characterization of alkaline keratinase from Streptomyces minutiscleroticus DNA38
}

\author{
Nandini Allure ${ }^{a}$, Madhusudhan D.N. ${ }^{b}$ and Dayanand Agsar ${ }^{c *}$ \\ A-DBT Research Laboratory, \\ Department of Microbiology, \\ Gulbarga University, Kalaburagi 585106, India \\ E-mail address: aallurenandini@gmail.com, ${ }^{b}$ sudhandn.dn@gmail.com, \\ ${ }^{* c}$ dayanandagsar@gmail.com
}

\section{Keywords: Streptomyces minutiscleroticus; Response Surface Methodology; keratinase;} purification; characterization

\begin{abstract}
A thermo tolerant, feather-degrading, newly isolated actinobacterial strain Streptomyces minutiscleroticus DNA38 was investigated for its ability to produce keratinase. Maximum production (283.4 IU) of keratinase by Streptomyces minutiscleroticus DNA38 in starch chicken feathers medium under submerged bioprocess was observed at optimized conditions of $\mathrm{pH}$ 9.0 of the medium and $45^{\circ} \mathrm{C}$ incubation temperature. Further, an enhanced production (435.8 IU) of keratinase was achieved employing response surface methodology. Combined interactive effect of starch $(7.50 \mathrm{~g} / \mathrm{L})$, yeast extract $(0.74 \mathrm{~g} / \mathrm{L})$ and chicken feathers $(7.50 \mathrm{~g} / \mathrm{L})$ were found to be the critical process variables for enhanced production under central composite design. Chicken feathers showed a direct action and addition of starch and yeast extract to the medium proved effective for a significant increase in the production of keratinase. The purified keratinase was monomeric and had a molecular mass of $29 \mathrm{kDa}$. The enzyme activity was significantly inhibited after $\mathrm{pH} 9.0$ and temperature $50{ }^{\circ} \mathrm{C}$.
\end{abstract}

\section{INTRODUCTION}

Chicken feather mainly contains keratin, which is an insoluble protein with high stability and indigestible by common proteases [1,2]. Actinomycetes have the ability to breakdown many different varieties of organic compounds and are crucial in the mineralization of organic matter [3]. Proteases constitute an important fraction of the global enzyme sales and a relevant part of this market is accounted by bacterial proteases [4]. Keratinases are projected to generate a potential worldwide market similar to other proteases. Bacterial keratinases are of particular interest because of their action on insoluble keratin substrates and generally on a broad range of protein substrates [5]. These enzymes have been studied for de-hairing processes in the leather industry [6]. Cultivation conditions are essential in successful production of enzyme, and optimization of parameters such as $\mathrm{pH}$, temperature and media composition are important in developing the cultivation process. Despite all the work that has been done on production of proteolytic enzymes, relatively little information is available on keratinases [7]. Upto now, a limited number of reports are available on the isolation of thermophiles, in particular thermophilic Streptomyces with the ability to hydrolyse wool and other keratinous wastes $[8,9]$.

Diverse groups of microorganisms are reported to produce keratinase [10-14]. However, the full commercial potential of keratinases is yet to be realized. At present, the major focus in this field is still rests in identifying novel isolates with high keratinase activity and improving the yield using conventional and r-DNA approaches, in addition to optimizing the physical and nutritional parameters to maximize keratinase yield. Microbial alkaline proteases for industrial uses are produced and studied mainly from Bacillus and Streptomyces. Little is known about proteases from other actinomycetes, Actinomycetes produce extracellular enzymes like proteases, chitinases, amylases etc. Actinomycetes, particularly Streptomycetes are known to secrete multiple proteases in culture medium [15]. With comparison to Bacillus spp, actinomycetes have been less explored 
for proteases. Using response surface methodology (RSM) for optimized production is an efficient way to design and predict the role of each ingredients in the resultant product.

Many keratinase were well characterized and reported. However, purification and characterization of keratinase obtained from different sources required to be carried out from the point of any novel properties or applications. Purification of an enzyme is generally a multi-step process. The techniques selected for enzyme purification should be moderate and native conformation of the enzyme protein should not change as a result of purification [16]. Commonly, the first step in enzyme purification is based on fractionation of proteins on the basis of solubility. Various chromatographic and electrophoretic techniques are known to be employed for the purification of enzymes. Most commonly used electrophoretic technique is Polyacrylamide Gel Electrophoresis (PAGE). Characterization of any enzyme or protein deals with physical properties like native molecular weight determination. It also deals with the study of chemical properties like optimum $\mathrm{pH}$, optimum temperature, energy of activation and kinetic properties. The activities optimal for $\mathrm{pH}$ of various enzymes vary. The present study reports the enhanced production of keratinase using RSM by Streptomyces isolated from the soil of poultry farm. Thus obtained keratinase was purified and also characterized.

\section{MATERIALS AND METHODS}

\section{Optimization of production of keratinase}

Keratinase was produced in a submerged bioprocess by Streptomyces minutiscleroticus DNA38 (a potential isolate for keratinase isolated and preserved in our A- DBT Research laboratory), at laboratory scale, employing $100 \mathrm{ml}$ starch chicken feathers broth [17]. Optimization of physicochemical and nutritional variables, employing one at a time experimental protocol [18] was followed for the production of keratinase. Initial $\mathrm{pH}$ (7.0 to 9.0 with an increment of 0.5), inoculum size $\left(1 \times 10^{5}\right.$ to $1 \times 10^{9}$ with an increment of $\left.1 \times 10^{1}\right)$, incubation temperature $\left(30\right.$ to $50{ }^{\circ} \mathrm{C}$ with an increment of $5{ }^{\circ} \mathrm{C}$ ), agitation speed (150 to $250 \mathrm{rpm}$ with an increment of $25 \mathrm{rpm}$ ), carbon sources (Starch, glucose, sucrose, maltose and sucrose, from 0.2 to $1.0 \%$ with an increment of $0.2 \%$ ), nitrogen sources (beef extract, casein, yeast extract and chicken feathers from 0.2 to $1.0 \%$ with an increment of $0.2 \%)$ and mineral salts $\left(\mathrm{CuSO}_{4}, \mathrm{MgSO}_{4}, \mathrm{FeSO}_{4}, \mathrm{MnSO}_{4}\right.$ and $\mathrm{K}_{2} \mathrm{HPO}_{4}$ from 0.01 to $0.05 \%$ with an increment of $0.01 \%$ ) were optimized manually for the production of keratinase.

The keratinase activity of the fermented broth was estimated by modified method of Cheng et al. [19] using keratin as a substrate. The reaction mixture containing $1 \mathrm{ml}$ of $1 \%$ keratin in phosphate buffer ( $\mathrm{pH} \mathrm{8.0)}$ and $0.5 \mathrm{ml}$ of enzyme (fermented broth) was incubated at $30^{\circ} \mathrm{C}$ for $30 \mathrm{~min}$. After incubation, the reaction was terminated by adding $2 \mathrm{ml}$ of $10 \%$ trichloroacetic acid (TCA). After the separation of untreated keratin as pellet by centrifugation, $1 \mathrm{ml}$ of clear supernatant was mixed with $5 \mathrm{ml}$ of $0.4 \mathrm{M} \mathrm{Na} 2 \mathrm{CO}_{3}$ and $0.5 \mathrm{ml}$ of Folin-Ciocalteau's phenol reagent. The absorbance was measured at $660 \mathrm{~nm}$ against blank after $30 \mathrm{~min}$. All assays were carried out in triplicate. One unit of keratinase activity was defined as the amount of enzyme that released one microgram of tyrosine per minute under the standard assay conditions.

\section{Enhanced production of keratinase}

The identified critical process variables namely Starch, yeast extract and chicken feathers, under response surface method were evaluated [20] with central composite design for their optimum combined effect on the production of keratinase in submerged bioprocess. The CCD of 33 runs was set using the Design Expert Software, USA (Version 7.0). All the experiments were carried out in duplicate and average of keratinase production obtained was considered as the dependent variables or responses $(\mathrm{Y})$. The predicted response was calculated from the second degree polynomial equation, $\mathbf{Y}=\boldsymbol{\beta}_{\mathbf{0}}+\sum \boldsymbol{\beta}_{\mathbf{i}} \mathbf{X}_{\mathbf{i}}+\sum \boldsymbol{\beta}_{\mathbf{i i}} \mathbf{X}_{\mathbf{i}}{ }^{2}+\sum \boldsymbol{\beta}_{\mathbf{i j}} \mathbf{X}_{\mathbf{i}} \mathbf{X}_{\mathbf{j}}$; where $\mathrm{Y}$ stands for the response variable, $\beta_{0}$ is the intercept coefficient; $\beta_{\mathrm{i}}$ represents the coefficient of the linear effect, $\beta_{\mathrm{ii}}$ the coefficient of quadratic effect and $\beta_{\mathrm{ij}}$ the $\mathrm{ij}^{\text {th }}$ interaction coefficient effect. $\mathrm{X}_{\mathrm{i}} \mathrm{X}_{\mathrm{j}}$ are input variables which influence the response variable $\mathrm{Y}, \beta_{\mathrm{i}}$ is the $\mathrm{i}^{\text {th }}$ linear coefficient. The statistical and numerical 
analysis of the model was performed with the analysis of variance (ANOVA). The statistical significance of the model was analyzed by the Fisher's F-test, its associated probability P (F), correlation coefficient $\mathrm{R}$ and determination coefficient $\mathrm{R}^{2}$. The quadratic models representing for each variable as contour plots (three-dimensional response surface curves) were created and the model was validated.

\section{Purification of keratinase}

The purification of keratinase produced by an efficient isolate Streptomyces minutiscleroticus DNA38 was carried out using crude enzyme extract as follows.

Ammonium sulphate precipitation: About $500 \mathrm{ml}$ of culture filtrate was centrifuged at 10,000 $\mathrm{rpm}$ for $10 \mathrm{~min}$ at $4{ }^{\circ} \mathrm{C}$ [21]. Finely powdered ammonium sulphate was added to the clear supernantent. The keratinase activity was associated with the fraction precipitated at $60-90 \%$ saturation. This was carried out with continuous stirring in an ice bath and it was kept at $4{ }^{\circ} \mathrm{C}$ for overnight. The precipitate was collected by centrifugation at $10,000 \mathrm{rpm}$ for $10 \mathrm{~min}$. The supernatant was decanted; the precipitate was dissolved in minimum volume of $10 \mathrm{mM}$ phosphate buffer $\mathrm{pH}$ 7.0. Protein estimation [22] was done with Folin-Phenol reagent using BSA (200 $\mu \mathrm{g} / \mathrm{ml})$ as a standard.

Dialysis: Activation of cellulose membrane was performed as follows [21]. $100 \mathrm{ml}$ distilled water was kept for boiling. Dialysis membrane was placed in water for 10 min. Then $2 \%$ sodium carbonate was added and further kept for boiling for $10 \mathrm{~min}$. Finally the membrane was transferred to fresh water. The precipitate obtained after ammonium sulphate treatment was dialyzed against 50 $\mathrm{mM}$ phosphate buffer, $\mathrm{pH} 7.0$ with occasional changes of buffer. Protein estimation [22] was done with Folin-Phenol reagent using BSA $(200 \mu \mathrm{g} / \mathrm{ml})$ as a standard.

Ion exchange chromatography: The dialyzed ammonium sulphate fraction was applied [21] to a column of DEAE cellulose. $2 \mathrm{~g}$ of DEAE cellulose was suspended in $10 \mathrm{Mm}$ Tris-Cl-NaCl $\mathrm{pH}-7.0$ and kept at $4{ }^{\circ} \mathrm{C}$ overnight. The column was equilibrated with $0.05 \mathrm{M}$ Tris-Cl, pH 7.0 Swollen DEAE cellulose was loaded into a chromatographic column and allowed to settle. The sample was loaded to top of the column. The unbound protein was eluted and the bound protein eluted with linear gradient of $\mathrm{NaCl}$. Each fraction was analyzed for enzyme activity and protein. The keratinase activity was assayed by following modified method of Cheng et al. [19] using a substrate keratin as described earlier. Protein estimation was done with Folin-Phenol reagent using BSA $(200 \mu \mathrm{g} / \mathrm{ml})$ as a standard [22].

Gel filtration chromatography: The concentrated enzyme solution was applied [21] to a Sephadex G-200 column (39x9 cm) and the sample was subjected to GPC using SEPHADEX G-75 (SIGMA ALDRICH). $2 \mathrm{~g}$ of SEPHADEX was suspended in $0.05 \mathrm{M}$ Tri-HCl $\left(\mathrm{pH} \mathrm{7.0)}\right.$ and kept at $4^{\circ} \mathrm{C}$ overnight. Before loading, the column was well equilibrated with $0.05 \mathrm{M}$ Tris-HCl. Swollen sephadex was loaded into a chromatographic column and allowed to settle. The $3 \mathrm{ml}$ of the sample was loaded to top of the column. The enzyme was eluted using $0.05 \mathrm{M}$ Tris $\mathrm{HCl}$ and flow rate was adjusted to $0.5 \mathrm{ml} / \mathrm{min}$. Different fractions were collected and each fraction was assayed for protein by taking absorbance at $280 \mathrm{~nm}$. Protein estimation [22] was done with Folin-Phenol reagent using BSA $(200 \mu \mathrm{g} / \mathrm{ml})$ as a standard.

Electrophoresis: SDS - PAGE was performed according to the modified method of Laemmli [23], with a separating acrylamide gel of $10 \%$ and stacking gel $5 \%$ containing $0.1 \%$ SDS. The gel was stained with coomassie brilliant blue R-250 and destained.

\section{Characterization of keratinase}

The purified keratinase was subjected to characterization by studying the influence of $\mathrm{pH}$ and temperature as physicochemical factors, by following the standard procedures as mentioned below. Enzyme activity was recorded under the influence of varied conditions. 
Influence of pH: The activity of keratinase was evaluated at different range of $\mathrm{pH}(3.5-10.0)$. Purified enzyme was incubated with $1 \%$ keratin and $0.05 \mathrm{M}$ phosphate buffer of $\mathrm{pH} 4-10$, with an increment of $\mathrm{pH} 0.5$, under assay conditions and the enzyme activity was determined as described earlier. The different buffers used were $0.1 \mathrm{M}$ acetate buffer ( $\mathrm{pH} 3.0$ - 6.5), 0.1 MTris-HCl (pH 7.08.0) and $0.1 \mathrm{M}$ glycine $\mathrm{NaOH}(\mathrm{pH} 8.0-10)$.

Influence of temperature: The activity of enzyme was determined by incubating the assay mixture at temperatures ranging from 10 to $100{ }^{\circ} \mathrm{C}$ with an increment of $10{ }^{\circ} \mathrm{C}$. The reactions were performed at optimum $\mathrm{pH}$ value of the enzyme [24].

\section{RESULTS AND DISCUSSION}

\section{Enhanced production of Keratinase}

An amount of 283.4 IU of keratinase was produced by Streptomyces minutiscleroticus DNA38 in starch feathers medium under submerged bioprocess, at optimized physicochemical and nutritional variables, considering manually one variable at a time and keeping others constant. $\mathrm{pH}$ 9.0 and temperature $45^{\circ} \mathrm{C}$ were showed a constant influence on the production of keratinase. Starch, yeast extract and chicken feathers were identified as most critical variables, keeping optimized $\mathrm{pH}$, temperature and other media components as constant, for the enhanced production of keratinase under response surface method with central composite design. The critical process variables are those, influence the enzyme activity on minimum variation in concentration of the process variables. The run 24 showed (Table 1) a maximum response on the production of keratinase with an actual value of 435.8 IU against predicted value of 441.83 IU. The closer similarity between actual and predicted values could reflect the accuracy and applicability of response surface method with CCD to optimize the process. A polynomial equation derived from the multiple regression analysis for the analysis of critical variables was as follows. Keratinase production $(\mathrm{Y})=409.38+14.72 \mathrm{X}_{1}+0.40 \mathrm{X}_{2}+53.05 \mathrm{X}_{3}-4.81 \mathrm{X}_{1}^{2}+14.23 \mathrm{X}_{2}^{2}-40.96 \mathrm{X}_{3}^{2}+6.54 \mathrm{X}_{1} \mathrm{X}_{2}+$ $2.92 \mathrm{X}_{1} \mathrm{X}_{3}-0.52 \mathrm{X}_{2} \mathrm{X}_{3}$, where, $\mathrm{X}$ was the response variable with $\mathrm{X}_{1}, \mathrm{X}_{2}$ and $\mathrm{X}_{3}$ as coded values for starch, yeast extract and chicken feathers respectively.

The model characteristic response for the production of keratinase employing ANOVA (Table 2) showed a high coefficient $R^{2}$ value of 0.8513 . If $R^{2}$ value is closer to 1 (should be between 0 and 1 and >0.75), the model would be stronger and it predicts the better response [25]. Thus, the statistical model could explain $97.09 \%$ of variability in the response. An F-value 14.63 and Lack of Fit value 31.38 were found to be significant. Adeq Precision ratio greater than 4 is desirable and in this investigation the ratio was 13.875. Three-dimensional response surface plots (Fig. 1) with a response at $120 \mathrm{~h}$ of incubation for keratinase production were on $\mathrm{Z}$ axis against any two independent variables, while keeping the other independent variable at their central level. Three response surfaces with all the possible combinations of critical variables starch $(7.5 \mathrm{~g} / \mathrm{L})$, yeast extract $(0.74 \mathrm{~g} / \mathrm{L})$ and chicken feathers $(7.5 \mathrm{~g} / \mathrm{L})$ given the maximum (435.8 IU) production of keratinase. However, a varied range of keratinase activities were reported by several researchers using different substrates. The recent literature reveals the production of $16.53 \mathrm{U} / \mathrm{ml}$ Streptomyces keratinase [26]. Shilpa Ashok Jani et al. [27] reported 92.810 Units/ml Streptomycetes keratinase activity and Ana Maria Mazotto [28] obtained $463 \mathrm{u} / \mathrm{mL}$ of keratinase activity from $B$. subtilis. In the present investigation an impressive level $(435.8 \mathrm{IU} / \mathrm{ml})$ production of alkaline keratinase was achieved, which can be explored further for competitive commercial viability. 
Table 1: Optimization of critical process variables for the production of keratinase by Streptomyces minutiscleroticus DNA38 under response surface method with central composite design

\begin{tabular}{|c|c|c|c|c|c|}
\hline \multirow{3}{*}{ Run } & \multicolumn{3}{|c|}{ Critical process variables } & \multirow{2}{*}{\multicolumn{2}{|c|}{$\begin{array}{c}\text { Keratinase } \\
\text { Production (IU) }\end{array}$}} \\
\hline & \multirow{2}{*}{$\begin{array}{c}\mathrm{X}_{1}: \mathrm{A}: \\
\text { Starch } \mathrm{g} / \mathrm{L}\end{array}$} & \multirow{2}{*}{$\begin{array}{c}\mathrm{X}_{2}: \mathrm{B}: \\
\text { Yeast extract } \mathrm{g} / \mathrm{L}\end{array}$} & \multirow{2}{*}{$\begin{array}{c}\mathrm{X}_{3}: \mathrm{C}: \\
\text { Chicken } \\
\text { feathers } \mathrm{g} / \mathrm{L}\end{array}$} & & \\
\hline & & & & $\begin{array}{l}\text { Actual } \\
\text { Value }\end{array}$ & $\begin{array}{c}\text { Predicted } \\
\text { value }\end{array}$ \\
\hline 1 & 10.0 & 1.0 & 05.0 & 340.1 & 329.13 \\
\hline 2 & 05.0 & 2.0 & 10.0 & 380.6 & 406.59 \\
\hline 3 & 05.0 & 1.0 & 10.0 & 402.7 & 419.91 \\
\hline 4 & 7.50 & 1.50 & 7.50 & 414.7 & 409.38 \\
\hline 5 & 3.69 & 1.50 & 7.50 & 341.7 & 375.75 \\
\hline 6 & 7.50 & 1.50 & 3.69 & 171.3 & 233.29 \\
\hline 7 & 7.50 & 1.50 & 7.50 & 413.2 & 409.38 \\
\hline 8 & 7.50 & 0.74 & 7.50 & 429.6 & 441.83 \\
\hline 9 & 7.50 & 1.50 & 7.50 & 415.1 & 409.38 \\
\hline 10 & 5.0 & 1.0 & 5.00 & 360.3 & 318.50 \\
\hline 11 & 7.50 & 1.50 & 11.31 & 425.2 & 395.05 \\
\hline 12 & 11.31 & 1.50 & 7.50 & 422.7 & 420.65 \\
\hline 13 & 7.50 & 1.50 & 3.69 & 179.7 & 233.29 \\
\hline 14 & 11.31 & 1.50 & 7.50 & 418.2 & 420.65 \\
\hline 15 & 7.50 & 2.26 & 7.50 & 425.7 & 443.06 \\
\hline 16 & 7.50 & 1.50 & 7.50 & 416.1 & 409.38 \\
\hline 17 & 7.50 & 2.26 & 7.50 & 426.8 & 443.06 \\
\hline 18 & 10.0 & 2.00 & 5.00 & 362.1 & 344.06 \\
\hline 19 & 7.50 & 1.50 & 7.50 & 415.9 & 409.38 \\
\hline 20 & 5.0 & 2.00 & 5.00 & 338.2 & 307.37 \\
\hline 21 & 10.0 & 2.00 & 5.00 & 370.6 & 344.06 \\
\hline 22 & 10.0 & 2.00 & 10.00 & 426.9 & 454.95 \\
\hline 23 & 5.0 & 2.00 & 5.00 & 336.3 & 307.37 \\
\hline 24 & 7.50 & 0.74 & 7.50 & 435.8 & 441.83 \\
\hline 25 & 10.0 & 1.00 & 10.00 & 429.1 & 442.11 \\
\hline 26 & 10.0 & 1.00 & 5.00 & 352.6 & 329.13 \\
\hline 27 & 5.0 & 1.00 & 5.00 & 335.1 & 318.60 \\
\hline 28 & 7.50 & 1.50 & 7.50 & 416.3 & 409.38 \\
\hline 29 & 5.0 & 2.00 & 10.00 & 428.3 & 406.59 \\
\hline 30 & 10.0 & 1.00 & 10.00 & 425.5 & 442.11 \\
\hline 31 & 3.69 & 1.50 & 7.5 & 358.3 & 375.75 \\
\hline 32 & 7.50 & 1.50 & 11.31 & 428.6 & 395.05 \\
\hline 33 & 5.00 & 1.00 & 10.00 & 422.7 & 419.91 \\
\hline
\end{tabular}


Table 2: Analysis of variance (ANOVA) for the assessment of the model

\begin{tabular}{lccccc}
\hline \multicolumn{1}{c}{ Source } & $\begin{array}{c}\text { Sum of } \\
\text { Squares }\end{array}$ & df & $\begin{array}{c}\text { Mean } \\
\text { Square }\end{array}$ & F Value & $\begin{array}{c}\text { p-value } \\
\text { Prob }>\text { F }\end{array}$ \\
\hline Model & $1.109 \mathrm{E}+005$ & 9 & 12324.10 & 14.63 & $<0.0001$ \\
$A$-Starch & 5169.37 & 1 & 5169.37 & 6.14 & $<0.0210$ \\
B-Yeast Extract & 3.86 & 1 & 3.86 & $4.585 \mathrm{E}-003$ & 0.9466 \\
C-Chicken feathers & 67109.73 & 1 & 67109.73 & 79.69 & $<0.0001$ \\
AB & 624.36 & 1 & 624.36 & 0.74 & 0.3981 \\
AC & 124.06 & 1 & 124.06 & 0.15 & 0.7046 \\
BC & 3.98 & 1 & 3.98 & $4.723 \mathrm{E}-003$ & 0.9458 \\
$\mathrm{~A}^{2}$ & 407.14 & 1 & 407.14 & 0.48 & $<0.4938$ \\
$\mathrm{~B}^{2}$ & 3564.48 & 1 & 3564.48 & 4.23 & $<0.0512$ \\
$\mathrm{C}^{2}$ & 29536.35 & 1 & 29536.35 & 35.07 & $<0.0001$ \\
Residual & 9368.78 & 23 & 842.12 & & \\
\hline
\end{tabular}
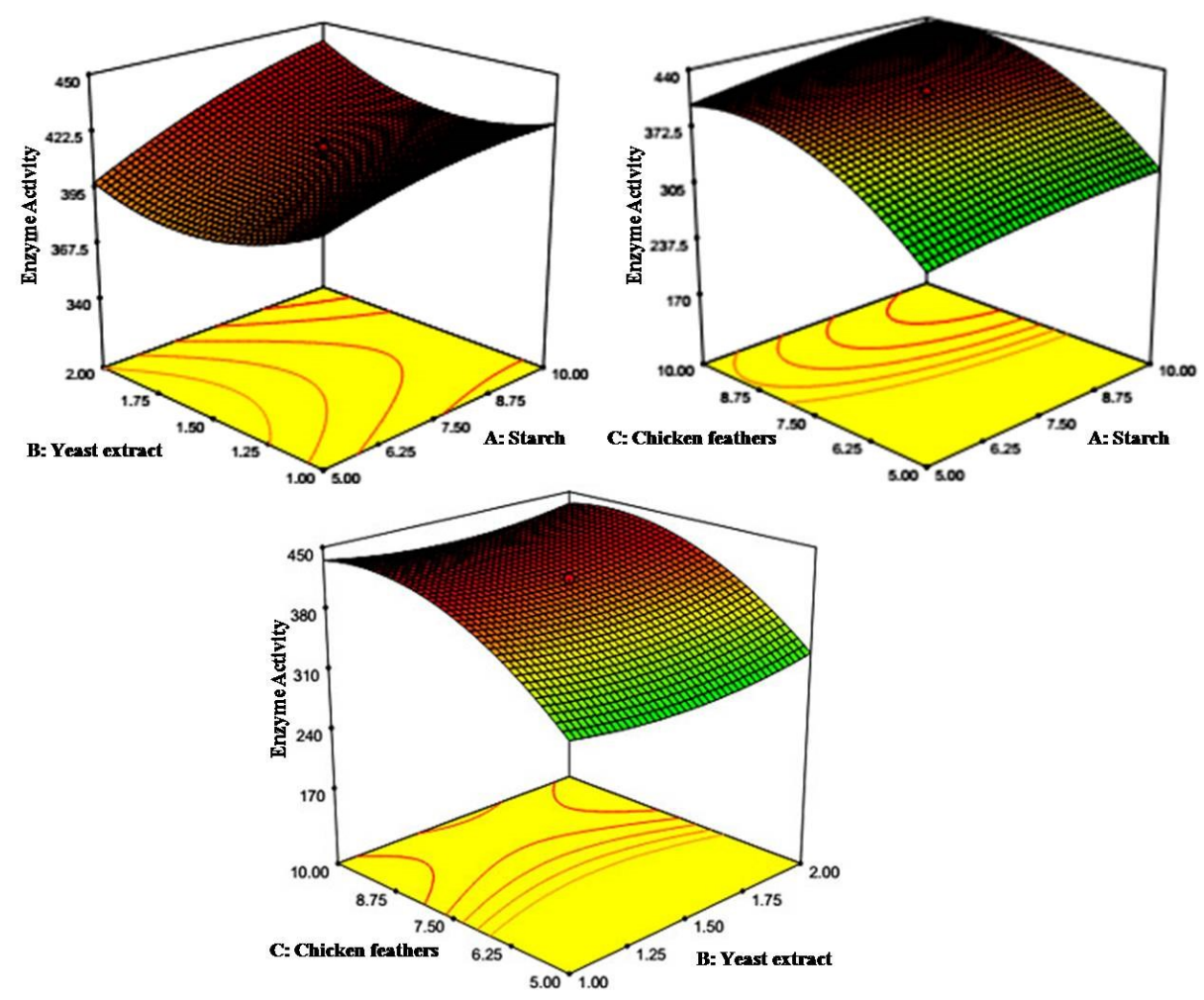

Fig. 1: Three dimensional response surface curves showing the interactive effect of critical process variables on the production of keratinase by Streptomyces minutiscleroticus DNA38

\section{Purification of keratinase}

Protein purification is a series of processes intended to isolate a single type of protein from a complex mixture and is also vital for the characterization of the function, structure and interactions of the protein of interest. The starting material is usually a biological tissue or a microbial culture. In the present investigation, purification of keratinase was carried out by four steps as shown in Table 2, with a final yield of $3.8 \%$ and a purification fold of 113.45 . The total protein decreased from $2846 \mathrm{mg}$ to $0.72 \mathrm{mg}$ and the specific activity increased from 30.56 to $58.85 \mathrm{IU} / \mathrm{mg}$ in the 
ammonium sulfate precipitation, which leads to a 2.68 fold purification of the keratinase. In the second step, the enzyme was subjected to dialysis. The specific activity of keratinase increased from 58.82 to $330.82 \mathrm{IU} / \mathrm{mg}$ leads to 15.10 fold purification of keratinase by dialysis. In the next two consecutive stages, ion exchange and gel exclusion chromatography, specific activity of keratinase was increased from 330.82 to $1171.6 \mathrm{IU} / \mathrm{mg}$ with 53.44 fold purification and $2486.9 \mathrm{IU} / \mathrm{mg}$ with 113.45 fold purification respectively. SDS-PAGE analysis of the purified enzyme showed a single band as represented in Fig. 2. The apparent molecular weight of the enzyme was determined to be $29 \mathrm{kDa}$ by using different standard protein markers.

Unlike most eukaryotic keratinases, the active form of the Pseudomonas sp. protein is a monomer, without tendency of concentration dependent aggregation as shown by analytical ultracentrifugation. The enzyme has a molecular mass of 39,000 Da in SDS-PAGE. A keratinase from a pseudomonas aeruginosa strain has been purified by a simple steps purification by Liu-Jung et al. [29]. This keratinase has one of the lowest (29 KDa) molecular masses among the known keratinases from different sources [30, 31, 32]. About $66 \mathrm{KDa}$ keratinase was reported, produced by Bacillus sp. JB99 was found to the largest sized keratinase [33]. In average, the size of the keratinase obtained by many researchers was in between the size of 35 to $45 \mathrm{KDa}[17,34,35]$. The molecular weight of the enzyme in the present study seems to be in the range with the data of other researchers as mentioned above.

Table 3: Purification profile of keratinase produced by Streptomyces minutiscleroticus DNA38

\begin{tabular}{|l|l|l|l|l|l|l|l|l|}
\hline $\begin{array}{l}\text { Purification } \\
\text { stage }\end{array}$ & $\begin{array}{l}\text { Volume } \\
(\mathrm{mL})\end{array}$ & $\begin{array}{l}\text { Enzyme } \\
\text { activity } \\
(\mathrm{IU} / \mathrm{mL})\end{array}$ & $\begin{array}{l}\text { Total } \\
\text { activity }\end{array}$ & $\begin{array}{l}\text { Protein } \\
(\mathrm{mg} / \mathrm{mL})\end{array}$ & $\begin{array}{l}\text { Total } \\
\text { Protein }\end{array}$ & $\begin{array}{l}\text { Specific } \\
\text { activity } \\
(\mathrm{IU} / \mathrm{mg})\end{array}$ & $\begin{array}{l}\text { Fold } \\
\text { purification }\end{array}$ & $\begin{array}{l}\% \\
\text { yield }\end{array}$ \\
\hline $\begin{array}{l}\text { Crude } \\
\text { fraction }\end{array}$ & 200 & 435.00 & 46800 & 14.23 & 2846 & 30.56 & 1 & 100 \\
\hline $\begin{array}{l}\text { Ammonium } \\
\text { sulphate } \\
\text { precipitation }\end{array}$ & 30 & 480.27 & 14408.1 & 8.16 & 244.8 & 58.85 & 2.68 & 30.7 \\
\hline $\begin{array}{l}\text { Dialysis/ } \\
\text { desalting }\end{array}$ & 12 & 516.09 & 6193.08 & 1.56 & 18.72 & 330.82 & 15.10 & 12.2 \\
\hline $\begin{array}{l}\text { Ion exchange } \\
\text { chromato- } \\
\text { graphy }\end{array}$ & 7 & 562.38 & 3936.66 & 0.48 & 3.36 & 1171.62 & 53.44 & 8.4 \\
\hline $\begin{array}{l}\text { Gel filtration/ } \\
\text { permeation }\end{array}$ & 3 & 596.86 & 1790.58 & 0.24 & 0.72 & 2486.91 & 113.45 & 3.8 \\
\hline
\end{tabular}

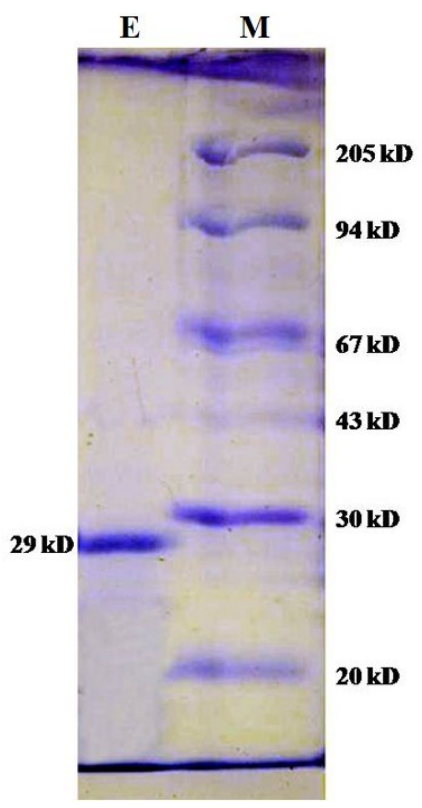

Fig. 2: SDS page profile of purified keratinase (E) compared with standard markers (M) 


\section{Characterization of keratinase}

Biochemical and enzyme kinetic properties of enzymes normally vary with the microbial sources. Properties of keratinase obtained from different microbial sources were recorded to be influenced by variations in $\mathrm{pH}$ and temperature. In the present study, a range of $\mathrm{pH}(5.0-10.0)$ was employed to evaluate the optimal $\mathrm{pH}$ for keratinase activity. The activity of keratinase was increased from $\mathrm{pH} 3.5$ to 8.5. The optimal $\mathrm{pH}$ for keratinase activity (437.2 IU) was observed at $\mathrm{pH}$ 9. Fig. 3 depicts the effect of $\mathrm{pH}$ on keratinase activity. Temperature is an important parameter that governs the enzyme activity. A range of temperature $\left(10-80{ }^{\circ} \mathrm{C}\right)$ was employed in present investigation to evaluate the optimal temperature for keratinase activity (Fig. 4). The activity of keratinase consecutively increased with a simultaneous increase with temperature in the range from $10^{\circ} \mathrm{C}-50^{\circ} \mathrm{C}$ and the optimal temperature for keratinase activity $(406.0 \mathrm{IU})$ was observed at $50{ }^{\circ} \mathrm{C}$. Fig. 4 depicts the effect of temperature on keratinase activity. The purified enzyme could able to show a stable and broad activity in presence different buffers. The purified keratinase showed maximum activity in phosphate buffer $(\mathrm{pH} 9.0)$ followed by $0.1 \mathrm{M}$ acetate buffer $(\mathrm{pH} 8.0)$ and 0.1 $\mathrm{M}$ glycine $\mathrm{NaOH}(\mathrm{pH} 8.5)$ and least activity was obsereved in the presence of $0.1 \mathrm{M}$ Tris-HCl (pH 9.0). Production of an alkaline keratinase by Streptomyces minutiscleroticus DNA38, with a tolerance of temperature up to $50^{\circ} \mathrm{C}$ is an important feature.

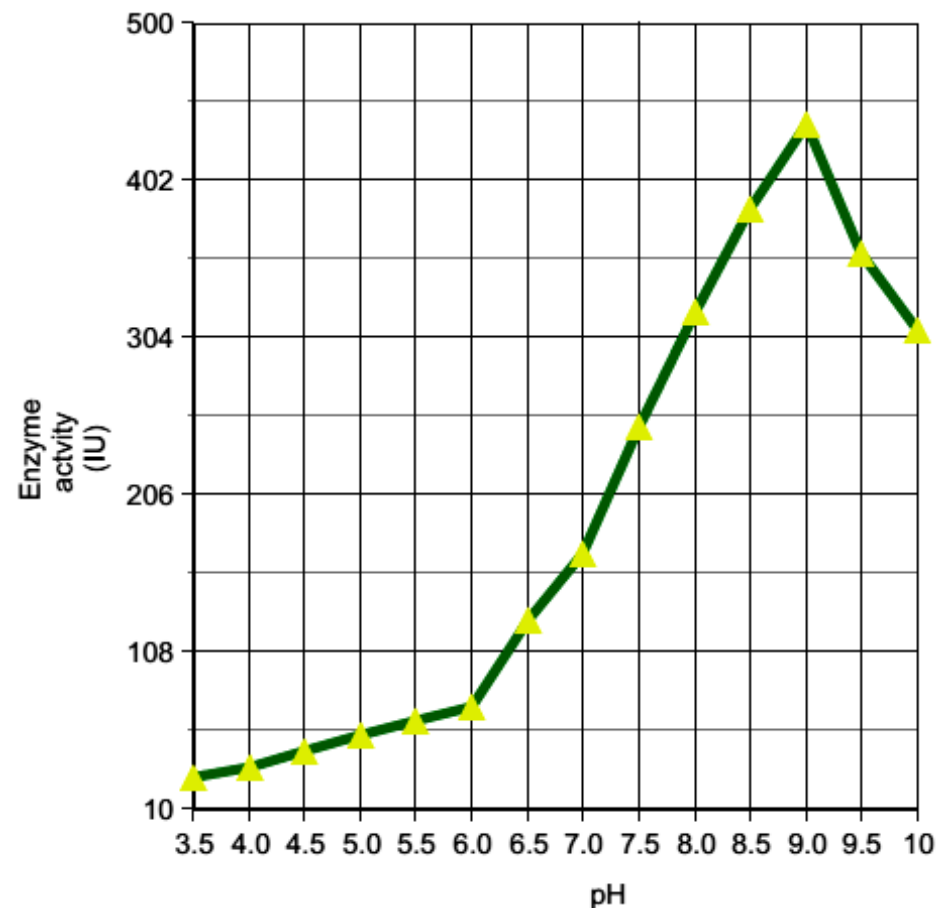

Fig. 3: Influence of $\mathrm{pH}$ on activity of keratinase 


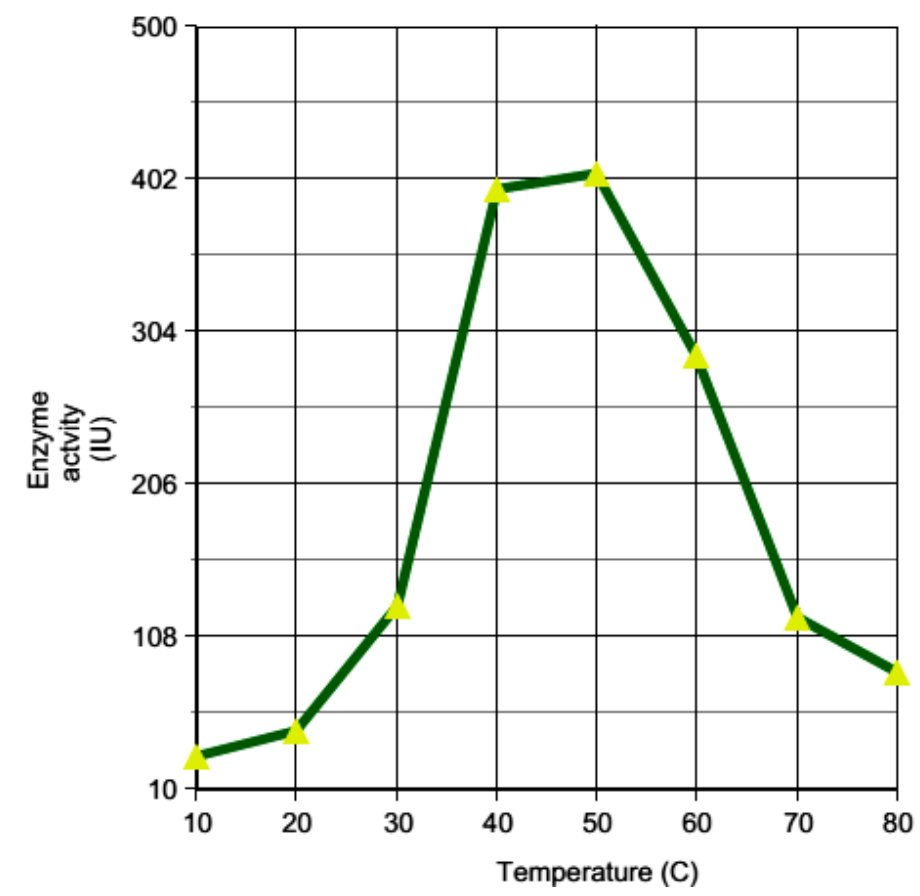

Fig. 4: Influence of temperature on activity of keratinase

\section{CONCLUSIONS}

A successful production of alkaline keratinase from an isolate of Streptomyces is a significant observation of the present investigation. An enhanced production (435.8 IU) of keratinase, in starch chicken feathers medium under submerged bioprocess was achieved by response surface methodology. The isolate had shown a greater consistency towards higher conditions of temperature $\left(45^{\circ} \mathrm{C}\right)$ and $\mathrm{pH}(9.0)$ for the maximum production of keratinase, using simple nutritional ingredients such as starch, yeast extract and chicken feathers. The purified keratinase revealed an activity of 596.86 IU with specific activity of 2486.91 indicating 113.45 fold purification by gel filtration. SDS page profile reveals a size of $29 \mathrm{KDa}$ of keratinase. Activity of purified keratinase was tolerant to a wide range of $\mathrm{pH}$ and temperature. However, $\mathrm{pH} 9.0$ and temperature of $50{ }^{\circ} \mathrm{C}$ were optimum for the maximum activity of keratinase. The results obtained showed that, newly isolated Streptomyces minutiscleroticus DNA38 could be a useful strain in biotechnology in terms of valorization of keratin containing wastes.

\section{References}

[1] D.R. Goddard, L. Michaels, A study of keratin, J.Biol Chem.106 (1934) 604-614.

[2] M.C. Papadopoulos, The effect of enzymatic treatment on amino acid content and nitrogen characteristics of feather meal, Anim. Feed Sci. Technol.16 (1986) 151-156.

[3] J. Ryckeboer, J. Mergaert, J. Coosemans, K. Deprins, J. Swings, Microbiological aspects of biowaste during composting in a monitored compost bin. Journal of Applied Microbiology. 94 (2003) 127-137.

[4] M.B. Rao, A.M. Tanksale, M.S. Ghatge, V.V. Deshpande, Molecular and biotechnological aspects of microbial proteases, Microbiology and MolecularBiology Reviews. 62 (1998) 597635.

[5] X. Lin, C.G. Lee, E.S. Casale, J.C.H. Shih, Purification and Characterization of a Keratinase from a Feather-Degrading Bacillus licheniformis Strain, Applied and Environmental Microbiology. 58 (1992) 3271-3275. 
[6] A.A. Raju, N.K. Chandrababu, N. Samivelu, C. Rose, N.M. Rao, Eco-friendly enzymatic dehairing using extracellular proteases from Bacillus species isolate, Journal of the American Leather Chemical Association.91 (1996) 115-119.

[7] J.J. Wang, J.C.H. Shih, Fermentation production of keratinase from Bacillus licheniformis PWD-1 and a recombinant B. subtilis FDB-29, Journal of Industrial Microbiology and Biotechnology. 22 (1999) 608-616.

[8] Z. Ignatova, A. Gousterova, G. Spassov, P. Nedkov, Isolation and partial characterisation of extracellular keratinase from a wool degrading thermophilic actinomycete strain Thermoactinomyces candidus. Canadian Journal of Microbiology 45 (1999) 217-222.

[9] P Kabadjova, S. Vlahov, M. Dalgalarrondo, X. Dousset, T. Haertle, L. Briand, J.M.. Chobert, Isolation and distribution of Streptomyces populations with heat-resistant collagenolytic activity from two protein-rich areasin Bulgarian soils. Folia Microbiologica. 41 (1996) 423429.

[10] M. Han, W. Luo, Q. Gu, X. Yu, Isolation and characterization of a keratinolytic protease from a feather-degrading bacterium Pseudomonas aeruginosa C11, African Journal of Microbiology Research. 6 (2012) 2211-2222.

[11]B. Deivasigamani, K.M. Alagappan, Industrial application of keratinase and soluble proteins from feather keratins, Journal of Environmental Biology. 29 (2008) 933-936.

[12]R.P. Mukhopadhyay, A.L. Chandra, Protease of a keratinolytic streptomycete to unhair goat skin, Indian Journal of Experimental Biology. 31 (1993) 557-558.

[13]G.W. Nam, D.W. Lee, H.S. Lee et al., Native-feather degradation by Fervidobacterium islandicum AW-1, a newly isolated keratinase-producing thermophilic anaerobe, Archives of Microbiology. 178 (2002) 538-547.

[14] Suneetha V., V.V. Lakshmi, Optimisation of parameters for fermentative production of keratinase by feather degrading microorganisms, World Journal of Microbiology and Biotechnology. 7 (2005) 106-115.

[15]R. Tatineni, K.K. Doddapaneni, R.C. Potumarthi et al., Purification and characterization of an alkaline keratinase from Streptomyces sp., Bioresource Technology, 99 (2008) 1596-1602.

[16]L. Kumar, B. Singh, K.D. Adhikari, J. Mutherjee, D. Ghosh, A temperature and salt tolerant Lglutaminase from Gangotri region of Uttarakhand Himalaya: enzyme purification and characterization. Appl. Biochem. Biotechnol. 166 (2012) 1723-1735.

[17] G.S. Dastager, J. Chan Lee, L. Wen - Jun, K. Chang - Jin, A. Dayanand, Production, characterization and application of keratinase from Streptomyces gulbargensis. Bioresour. Technol. 100 (2009) 1868-1871.

[18] Y. Liuan, G. Su, B. Zhang, G. Jiang, B. Yan, Nanoparticle-based strategies for detection and remediation of environmental pollutants, Journal The Royal Society of Chemistry (2010).

[19]S.W. Cheng, H.M. Hu, S.W. Shen, H. Takagi, M. Asano, Y.C. Tsai, Production and characterization of keratinase of a feather- degrading Bacillus licheniformis PWD-1. Biosci. Biotechnol. Biochem. 59 (1995) 2239-2243.

[20] Annapurna Kumari, Paramita Mahapatra, Rintu Banerjee, Statistical Optimization of Culture Conditions by Response Surface Methodology for Synthesis of Lipase with Enterobacter aerogenes, Braz. Arch. Biol. Technol, 52 (2009) 1349-1356.

[21]R. Wenk, Fernandis Aaron Zefrin, Manuals in Biomedical Rsearch - Vol. 3. A manual for Biochemistry Protocols. Jan - Thorsten Schantz (Eds.). World Scientific publishing Co. Pte. Ltd. Singapore. (2007) 
[22] O.H. Lowry, N.J. Rosenbrough, A.L. Farr, R.J. Randal, Protein measurement with Folin-phenol reagent, J. Biol. Chem. 193 (1951) 265-75.

[23]U.K. Laemmli, Cleavage of structural proteins during the assembly of the bacteriophage $t 4$. Nature. 227 (1970) 680-685.

[24]N. Liu, T. Zhang, Y.J. Wang, Y.P. Huang, J.H. Ou, P. Shen, A heat inducible tyrosinase with distinct properties from Bacillus thuringiensis. Letters in Applied Microbiology. 39 (2001) 407-412.

[25]P.D. Haaland (Ed.) Separating Signals from the Noise. In: Experimental Design in Biotechnology. Marcel Dekker, New York, 1989, pp. 61-83.

[26]P. Jayalakshmi, G. Krishnamoorthy, P. Ramesh kumar, Sivamani, Optimization of culture conditions for Keratinase production in Streptomyces sp. JRS19 for Chick feather wastes degradation, J. Chem. Pharm. Res., 3 (2011) 498-503.

[27] Shilpa Ashok Jani, Raval Heta, Harnisha Patel, Drashti Darji, Ankit Rathod, Seema Pal, Production and characterization of keratinolytic protease from Streptomyces sp., Int. J. Curr. Microbiol. App. Sci. 4 (2015) 962-975.

[28] Ana Maria Mazotto, Rosalie Reed Rodrigues Coelho, Sabrina Martins Lage Cedrola, et al., Keratinase Production by Three Bacillus spp. Using Feather Meal and Whole Feather as Substrate in a Submerged Fermentation, Enzyme Research. Article ID 523780, 7 pages. doi:10.4061/2011/523780. (2011).

[29] Li-Jung Yin, Jein-Hwa Lee, Shann-Tzong Jiang, Isolation of a Keratinase-Producing Bacterium and purification of its keratinase, J. Fish. Soc. Taiwan. 33 (2006) 377-390.

[30]Xiang Lin, Chung-Ginn Lee, S. Ellen Casale, C.H. Jason Shih, Purification and Characterization of a Keratinase from a Feather-Degrading Bacillus licheniformis Strain, Applied and Environmental Microbiology. (1992) 3271-3275.

[31]Brigitte Bockle, Boris Galunsky and Rudolf Muller, Characterization of a Keratinolytic Serine Proteinase from Streptomyces pactum DSM 40530, Applied and Environmental Microbiology. (Oct. 1995) 3705-3710.

[32]C.A.I. Cheng-Gang, Ji-Shuang Chen, Q.I. Jiong-Jiong, Yun Yin, Xiao-Dong Zheng. Purification and characterization of keratinase from a new Bacillus subtilis strain, J. Zhejiang Univ. Sci. B. 9 (2008) 713-720.

[33] S.K. Pushpalata, G.R. Naik, Production and characterization of feather degrading keratinase from Bacillus sp. JB 99, Indian Journal of Biotechnology. 9 (2010) 384-390.

[34] Venkata Saibabu, Francois Niyongabo Niyonzima and S. Sunil More, Isolation, Partial purification and Characterization of Keratinase from Bacillus megaterium, Int. Res. J. Biological Sci. 2 (2013) 13-20

[35] Sreenivasa Nayaka, K Gireesh Babu, G.M. Vidyasagar, Purification and characterization of keratinase from hair-degrading streptomyces albus. International Journal of Bioassays. 2 (03) (2013), 599-604. 